\title{
Post-traumatic cerebral infarction: a rare complication in a pediatric patient after mild head injury
}

\author{
Posttravmatik serebral iskemi: Pediyatrik yaş grubunda minör kafa travması \\ sonrası gelișen nadir bir komplikasyon
}

\author{
Serkan YILMAZ, ${ }^{1}$ Murat PEKDEMIR, ${ }^{1}$ Hasan Tahsin SARISOY, ${ }^{2}$ Elif YAKA ${ }^{3}$
}

\begin{abstract}
Because the cases of post-traumatic cerebral infarction in children are uncommon, little research has been done on this subject. The case of a 14-month-old child who had cerebral infarction after mild head injury is discussed. He fell from a height of approximately $70 \mathrm{~cm} 12$ hours before. He did not use his left arm after the injury. His parents took him to the public hospital, where he was investigated in terms of mechanical complication and was observed for six hours, but no computed tomography (CT) scan was performed at that time. The patient was then presented to our department by his parents. He was not able to walk and was sitting. His neurological examination revealed right hemihypoesthesia, hemiparesis and mild left facial paresis. CT showed a hypodense region in the right basal ganglia location. The right lateral ventricle seemed mildly compressed due to edematous changes. The magnetic resonance imaging revealed hyperintense signal changes that affected the right lentiform nucleus and the head of the caudate nucleus. The aim of the case is to remind emergency physicians that post-traumatic ischemic stroke is uncommon but may be the cause of disability in pediatric patients, and a systematic physical examination must be performed in all ages even if the patients appear quite well.
\end{abstract}

Key Words: Cerebral ischemia; minor head trauma; pediatric patient.
Çocukluk çağında travma sonrası görülen serebral iskemi oldukça nadirdir. Bu konuda çok az çalışma yapılmıştır. Burada minör kafa travması sonrası, 14 aylık pediyatrik bir hastada görülen serebral iskemi olgusu sunuldu. 14 aylık bir çocuk 12 saat önce 70 santimetre yükseklikten düşme sonrası sağ kolunu kullanamama şikayetiyle acil servise getirildi. Hastanın daha önce gittiği hastanede minör kafa travması olarak izlendiği ve kraniyal görüntülemenin yapılmadığı öğrenildi. Hastanın kolunu kullanamaması mekanik bir komplikasyon olarak görülmüş ve bu monoparazi olarak değerlendirilmemişti. Hasta başvurduğu sırada yürüyemediği ve oturamadığı da belirlendi. Minör kafa travmalı hastada başka bir travma izine rastlanmadı. Yapılan nörolojik muayenesinde hafif bir sağ hemiparazi ve sol fasiyal paralizi saptandi. Çekilen beyin tomografisinde sağ bazal ganglionlar seviyesinde hipodens görüntü tespit edilen hastanın MRG'sinde sağ lentiform ve caudat nukleusları sevisinde enfarktüs saptandı. Bu yazının amacı, acil servis hekimlerine pediyatrik yaş grubunda nadir görülmesine rağmen kalıcı sakatlıklara yol açabilen posttravmatik serebral iskemiyi ve hangi yaş grubunda olursa olsun ve hasta ne kadar iyi görünürse görünsün sistemik fiziksel incelemenin tüm hastalara uygulanması gerektiğini hatırlatmaktır.

Anahtar Sözcükler: Serebral iskemi; minör kafa travması; pediyatrik hasta.
A 14-month-old boy fell from a height of approximately $70 \mathrm{~cm} 12$ hours before. He did not lose consciousness and had no nausea or vomiting, but he cried for an extended period. His parents took him to the public hospital. He was investigated in term of me- chanical complication and was observed for six hours, but no computed tomography (CT) scan was performed at that time. In time, the patient was unable to walk, so his parents became agitated and brought him to our department of their own initiative.

\footnotetext{
Departments of ${ }^{1}$ Emergency Medicine, ${ }^{2}$ Radiodiagnostic, Kocaeli University, Faculty of Medicine, Kocaeli; ${ }^{3}$ Department of Emergency Medicine, Bayburt State Hospital, Bayburt, Turkey.
}

Kocaeli Üniversitesi Tıp Fakültesi ${ }^{1}$ Acil Tıp Anabilim Dalı, ${ }^{2}$ Radyodiagnostik Anabilim Dalı, Kocaeli; ${ }^{3}$ Bayburt Devlet Hastanesi Acil Servis, Bayburt. 


\section{CASE REPORT}

On admission to our hospital, his vitals were as follows: blood pressure, $85 / 55 \mathrm{mmHg}$; pulse, $108 / \mathrm{min}$; respiratory rate, $30 / \mathrm{min}$; body temperature, $36.8^{\circ} \mathrm{C}$ and $\mathrm{O}_{2}$ saturation, 97\%, He was alert (Glasgow Coma Scale $[\mathrm{GCS}]=15, \mathrm{E}=4, \mathrm{~V}=5, \mathrm{M}=6)$. The patient had no signs of head trauma; the pupils were equal and reactive. The motor and sensory examination revealed right hemihypoesthesia and hemiparesis. On his cranial nerve examination, he had a mild left facial paresis. He was not able to walk and was sitting. Other system examinations were also within normal limits.

Computed tomography (CT) showed a hypodense region in the right basal ganglia location. The right lateral ventricle seemed mildly compressed due to edematous changes (Fig. 1a). Magnetic resonance imaging obtained with turbo spin echo (TSE) T2-weighted and FLAIR (fluid attenuated inversion recovery) images depicted hyperintense signal changes that affected the right lentiform nucleus and the head of the caudate nucleus (Figs. 1b). Prominent diffusion restriction was revealed in the diffusion-weighted images (Fig. 1c), which proved that the incident was ischemic in nature.

It was thought that the child might have fallen as a result of an acute infarction. This possibility was more likely than the child having an infarction because of the fall. For that reason, the patient was admitted to the hospital for close observation. To exclude the possibility of a genetic predisposition to thrombosis, platelet count with peripheral blood smear examination, erythrocyte sedimentation rate, liver function test, lipid profile, and plasma homocysteine levels were evaluated, all of which were normal. To exclude the embolic cause of the infarct, echocardiography and carotid Doppler examination were also performed, all of which were normal.
The patient was treated conservatively with osmotic diuretic agent and dextran. His hemiparesis improved gradually, and by post-trauma day 10 , he was able to walk the patient was discharged slightly hobbled.

\section{DISCUSSION}

While minor bumps to the head are a very common occurrence in childhood, cerebral infarction is an exceedingly rare sequela. The calculated annual hospital frequency rate of stroke was $13-27 / 100,000$ in the pediatric (1 month-12 years) population. ${ }^{[1,2]}$

The pathophysiology of stroke after mild head injury in young children may be either thrombus or spasm in the lenticulostriate branches of the middle cerebral artery. The relative delay of symptoms in most of the cases can be explained on the basis of thrombus generation and immediate onset of symtoms can be explained mechanical disruption of blood or spasm. ${ }^{[3]}$ Early diagnosis and treatment are not possible because the post-traumatic ischemic stroke in a child is relatively rare; many of the patients do not lose consciousness and disease symptoms may begin late. In our case, neurological symptoms began 6 hours later and the first neuroimaging study was performed at that time.

Many risk factors are identified in children for ischemic stroke. Salih et al. ${ }^{[1]}$ revealed that a major risk factor was identified in $89.4 \%$ of the study population. Hematological disorders, presumed prenatal ischemic cerebral injury and infectious and inflammatory disorders of the circulatory system were the most common risk factors.

Although detailed investigation usually reveals risk factors for stroke in the majority of the affected children, none was identified in a small group of patients. Our patient was investigated for risk factors for stroke,
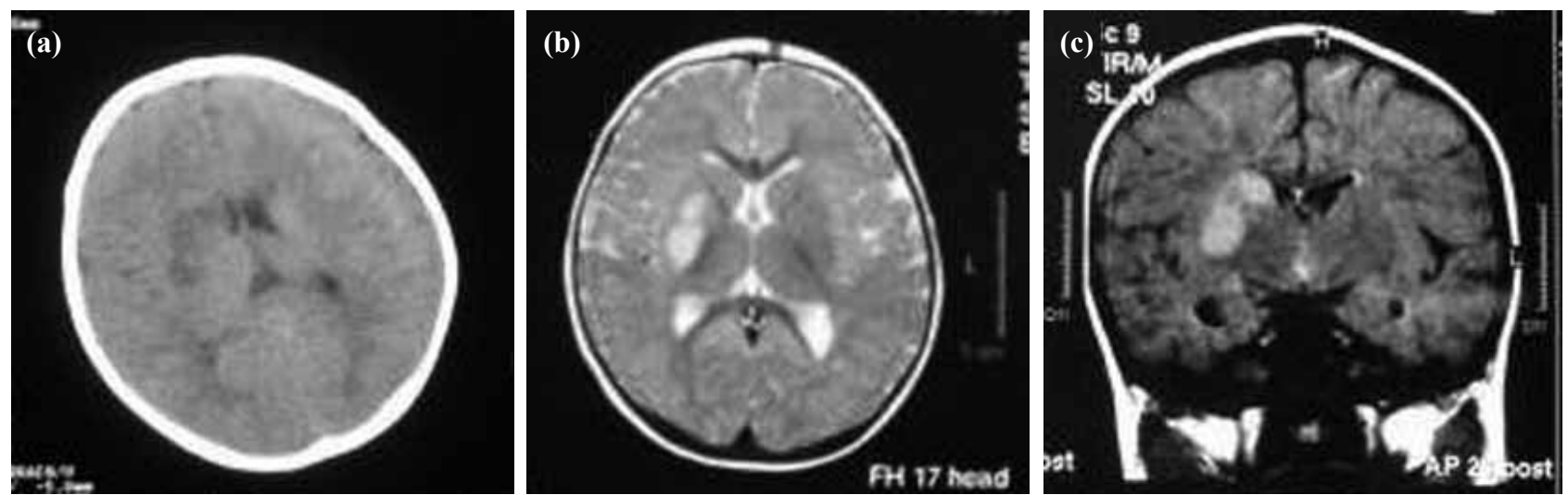

Fig. 1. (a) Unenhanced brain CT shows hypodense appearance in the right basal ganglia consistent with infarction. Due to mild edema of the infarction, the right lateral ventricle was compressed. (b) T2-weighted turbo-spin echo, axial brain magnetic resonance image reveals prominent hyperintensity in the right lentiform nucleus. (c) The coronal FLAIR (fluid attenuated inversion recovery) image demonstrates edematous changes in the right lentiform nucleus and the head of the nucleus caudatus. The intensity changes are attributed to acute ischemia. 
but no hematological, cardiac or metabolic risk factor was identified. It is thought that stretching and distorting the angle of lenticulostriate branches of the middle cerebral artery led to damage to the vessel, e.g., by either thrombus or spasm, with a consequent decrease in local blood flow. The result was an infarct in the basal ganglia. The immediate contralateral hemiparesis may have been caused by ischemic changes.

Children older than 2 years have been evaluated, managed and studied differently than those less than 2 years old. Neuroimaging criteria for children aged 2 years and younger remain undefined. One obvious reason is the GCS was developed for adults. The verbal portion of the GCS is not applicable to children with a developmental age of 2 or less. ${ }^{[4]}$ Although attempts have been made to develop a coma scale for younger children, there continues to be a lack of a uniformly accepted scale. Evidence strongly supports a lower threshold to perform a CT scan in younger children because they have a higher risk of significant brain injury after blunt head trauma. ${ }^{[5]}$
Many uncertainties remain concerning the nature of post-traumatic infarction in childhood. Further investigation, for developing diagnostic modalities and risk stratification, is important to prevent post-traumatic ischemic strokes, especially in young children.

\section{REFERENCES}

1. Salih MA, Abdel-Gader AG, Al-Jarallah AA, Kentab AY, Alorainy IA, Hassan $\mathrm{HH}$, et al. Stroke in Saudi children. Epidemiology, clinical features and risk factors. Saudi Med J 2006;27 Suppl 1:12-20.

2. Rana KS, Behera MK, Adhikari KM. Ischemic stroke following mild head injury is it the cause. Indian Pediatr 2006;43:994-7.

3. Kieslich M, Fiedler A, Heller C, Kreuz W, Jacobi G. Minor head injury as cause and co-factor in the aetiology of stroke in childhood: a report of eight cases. J Neurol Neurosurg Psychiatry 2002;73:13-6.

4. Savitsky EA, Votey SR. Current controversies in the management of minor pediatric head injuries. Am J Emerg Med 2000;18:96-101.

5. Thiessen ML, Woolridge DP. Pediatric minor closed head injury. Pediatr Clin North Am 2006;53:1-26. 